\title{
COMPARATIVE STUDY OF THE RELEVANCE OF EQUITY FINANCING IN EUROPEAN SMES
}

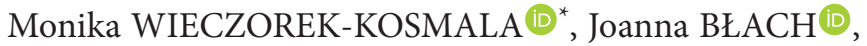 \\ Joanna TRZĘSIOK
}

University of Economics in Katowice, 1 Maja 50, 40-286 Katowice, Poland

Received 21 November 2019; accepted 18 May 2020

\begin{abstract}
This paper contributes to the academic debate on the pecking order theory and SMEs equity financing, in this equity financing gap. In order to address this problem, this study relies on the empirical design that is driven by the premises of the pecking order theory and distinguishes between the relevance of internal funds vs. external equity. The main aim of this study is to investigate whether the relevance of equity financing for European SMEs is driven by the country-specifics (captured by the clusters of the EU countries) and whether there are any other factors that may potentially explain the relevance of internal funds or external equity, with respect to SMEs performance and characteristics. For that purposes the SAFE survey data were used to run non-parametric and correlations analysis. The results have clearly indicated that there are statistically significant differences between the clusters of the EU countries (if we differentiate between core and peripheral EU countries in particular). It was also found that there is no unified pattern of the associations between the relevance of equity financing and SMEs performance and characteristics, thus these associations seem to be influenced by the country-specifics as well.
\end{abstract}

Keywords: SMEs, EU member states, equity financing, internal funds, external equity, capital structure, pecking order, equity capital gap.

JEL Classification: G32, M21.

\section{Introduction}

Sufficient access to funds is the key determinant for the development of SMEs. As proved by Kersten et al. (2017) SMEs finance have a positive significant impact on firm performance, capital investment and employment. However, SMEs often face various problems while searching for the new sources of funds. According to Kumar and Rao (2015) the major problems associated with inadequate finance for SMEs are (i) accessibility of limited financial sources (demand gap) due to the effect of various quantitative and qualitative variables on capital structure of SMEs, (ii) limited availability of finance for SMEs (supply gap), (iii) lack

*Corresponding author. E-mail: m.wieczorek-kosmala@ue.katowice.pl

Copyright (c) 2020 The Author(s). Published by Vilnius Tech Press

This is an Open Access article distributed under the terms of the Creative Commons Attribution License (http://creativecommons. org/licenses/by/4.0/), which permits unrestricted use, distribution, and reproduction in any medium, provided the original author and source are credited. 
of awareness about the accessibility of potential sources of finance (knowledge gap) and (iv) reluctance of financial institutions to provide funds to SMEs (benevolence gap). The supply gap and the knowledge gap was also identified by Cowling et al. (2012) and Daskalakis et al. (2013). Various financing patterns of SMEs addressing the problem of financing gap were identified and analysed by Ou and Haynes (2006), Whittam and Wyper (2007), Moritz et al. (2016) and Masiak et al. (2020). Some studies refer exclusively to debt financing gap (Colombo \& Grilli, 2007; Neely \& Van Auken, 2012; Andrieu et al., 2018), while others focus on equity financing gap (Mason \& Harrison, 1995; McNally, 1997; Carpenter \& Petersen, 2002; Durvy, 2007; Deffains-Crapsky \& Sudolska, 2014; Dowling et al., 2019).

This paper addresses the problem of equity financing gap in SMEs and contributes to the academic debate by shedding some light on the relevance of equity financing in SMEs performing in the EU member states. More specifically, the paper aims at investigating the problem of SMEs equity financing in two aspects. In the first aspect, it investigates the possible impact of country-specifics on the declared relevance of internal funds and external equity by the SMEs performing across the EU. However, it does not focus on a single-country effect, but on the effect observable within the clusters of the EU countries and for that purposes the EU member states were stratified in several dimensions. In the second aspect, an expanded analysis of the factors that are potentially related to the changing relevance of equity financing needs of SMEs was performed, broken by the given clusters of EU member states. These factors were captured by two sets of variables: the variables related to SMEs financial performance and the set of variables that indicate the most common SMEs characteristics. In the empirical design, the study relies on data obtained in the Survey of Access to Finance of Enterprises (SAFE), which is the joint endeavour of the European Commission and European Central Bank (European Commission, 2018). The results of the survey are published annually, by this offering a possibility to follow the trends in changing SMEs access to various sources of finance.

In the conceptual dimension, this study is framed on the premises of pecking order theory. As suggested by Donaldson (1961/2000) and further developed by Myers and Majluf (1984), according to the pecking order theory (POT) the observed capital structures reflect the relationship between internally available funds and investment requirements. The POT suggests that companies have a hierarchy of preferences with respect to sources of funds. This is the consequence of asymmetric information between management and potential capital providers. This may cause firms to avoid raising external equity by issuing new shares, and as a consequence they may be forced to postpone or to cancel valuable investment opportunities. In these circumstances, companies will prefer to use internal funds; they will avoid new equity issues and their borrowing will be determined as a residual between desired investment and the supply of retained earnings. In this study we focus on equity financing, by distinguishing between internal funds and external equity, and their relevance for SMEs' which is consistent with the "bridged pecking order theory" (BPOT). The BPOT assumes that SMEs move directly from self-funding to external equity in preference to, or instead of bank finance, as suggested by Whittam and Wyper (2007). The importance of internal funds as the major source of funds for smaller firms is discussed by Ou and Haynes (2006), who declared that the significance of external equity for SMEs seems to be overstated. 
The remainder of the paper is structured as follows. The first section briefly addresses the two underlying theoretical concepts behind this study: the problem of SMEs financing gap, with reference to the assumptions of pecking order theory and capital structure decisions. The second section explains the research design and methodology. The third section presents and discusses the results of empirical investigations. The fourth section concludes.

\section{Pecking order theory and capital structure decisions in SMEs - brief overview of the relevant literature}

The pecking order theory (POT) is one of the major theoretical approach that was developed to explain the capital structure decisions in enterprises. Firstly, it was proposed by Donaldson (1961/2000) and further developed by Myers and Majluf (1984) for the financing decisions in the imperfect world with asymmetric information and transaction costs (Leland et al., 1977). POT was created as an alternative to the static trade-off theory (TOT) and the assumption of the optimal capital structure presented by Kraus and Litzenberger (1973). POT suggests that firms do have a certain hierarchy of preferences with respect to sources of funds. Due to lower transaction and information costs, the internal funds (i.e. retained profit) is regarded as the first preference. Debt financing is the next preference as it gives opportunity of financial leverage and tax shield effect. External equity by issuing new shares is the last preference due to significant issuing costs and potential changes in the ownership structure. This order of preferences is related to the signaling hypothesis, firstly proposed by Ross (1977).

Higher transaction costs and the threat of sending negative signals may cause firms to avoid raising equity by issuing new shares. It results in using internal funds and maintaining reserve borrowing capacity together with financial slack. It has also consequences for the dividend policy of a company, as dividend payments are treated as residuals. This preference for internal funds is supported by research that found that managers often choose "the path of least resistance" when it comes to financing.

The pecking order theory (POT) was tested as an alternative to other theoretical models of capital structure, i.e. the static trade-off theory (TOT) or market-timing theory (MTT). The most relevant works in this stream of literature are Baskin (1989), Allen (1993), Shyam-Sunder and Myers (1999), Frank and Goyal (2003), Jong et al. (2011), Dong et al., (2012), Adair and Adaskou (2015). However, the evidence is mixed. Some empirical tests confirmed the pecking order theory (at least in some aspects for particular groups of firms), e.g. Baskin (1989), Allen (1993), Zoppa and McMahon (2002), Haas and Peeters (2006), Wu et al. (2008), Bulan and Zhipeng (2010), Bistrova et al. (2011), Jong et al. (2011), Adair and Adaskou (2015), Arsov and Naumoski (2016). On the other hand, there are numerous studies that have provided evidence to reject POT explanation. These studies predominantly confirmed that trade-off theory (developed by Kraus \& Litzenberger, 1973) or market-timing theory (presented by Baker \& Wurgler, 2002) far better explain firms' capital structure decisions (e.g. Frank \& Goyal, 2003; Delcoure, 2007). However, pecking order theory was confirmed for sample of SMEs in research by: Zoppa and McMahon (2002) for Australian SMEs; Wu et al. (2008) for Chinese SMEs; and Adair and Adaskou (2015) for French SMEs. 
Additionally, the importance of internal funds for SMEs was confirmed by Ou and Haynes (2006), Daskalakis et al. (2013) and Moritz et al. (2016) as they identified group of internally financed firms. Whittam and Wyper (2007) proposed the bridged pecking order (BPOT) indicating that SMEs move directly from internal funds to external equity (instead of bank loan). As they suggested, two reasons can be used to explain this situation. First, entrepreneurs consider debt to be a personal liability which requires to be underwritten by personal guarantees. Second, entrepreneurs deliberately seek out equity investment as a means of obtaining added value over and above the finance invested, as a well-chosen investor can add business skills and social capital in the form of commercial contacts and access to relevant networks. In this situation, rather than the external equity being viewed as expensive, it is viewed as good value (Whittam \& Wyper, 2007). However, SMEs access to typical external equity in a form of issuance of new shares may be limited due to high transaction costs, demanding disclosure requirements and strict capital market regulations. In order to reduce this equity gap new mechanisms and financing methods are continuously created and implemented, such as: state and EU programmes improving the access to private equity financing (both venture capital funds and business angels), alternative investment markets (AIM) dedicated to SMEs (that offer the possibility to acquire funds in the capital market with relaxed regulations) or crowdfunding platforms that provide innovative ways to gather funds by start-ups from a dispersed, unlimited cyber society. The initiatives aiming at support and development of crowdfunding financing, as well as, the private equity financing, are of special importance for SMEs in the early stages of life cycle.

\section{Research design and method}

Provided that there are numerous evidences on the phenomenon of equity financing gap in SMEs (as one of the dimensions of financing gap), this study addresses the relevance of internal funds and external equity in European SMEs. The map of the research design of this study is presented in Figure 1. In the conceptual dimension, this study is framed within the assumptions of pecking order theory. In methodological context, the study is designed to investigate three research questions that allow to shed some light on the drivers of the relevance of equity financing (both internal funds and external equity) in European SMEs:

RQ 1. Are the declarations on the relevance of equity financing of European SMEs country-specific?

RQ2. Is there any pattern of associations between the relevance of equity financing and the financial performance of SMEs similar in each cluster of the EU countries?

RQ3. Is there any pattern of associations between the relevance of equity financing and SMEs characteristics similar in each cluster of the EU countries?

The importance of the country-specific factors for the capital structure decisions has been discussed and analysed in numerous empirical studies, with mixed results. Some studies confirmed the significance of the country-specific factors, such as: economic growth and inflation rate, model of financial system, legal regulations, corporate governance model, monetary and fiscal policy, development of the capital market (e.g. Nivorozhkin, 2004; Delcoure, 2007; Kędzior, 2012; Koralun-Bereźnicka, 2013). The macroeconomic and institutional factors were 


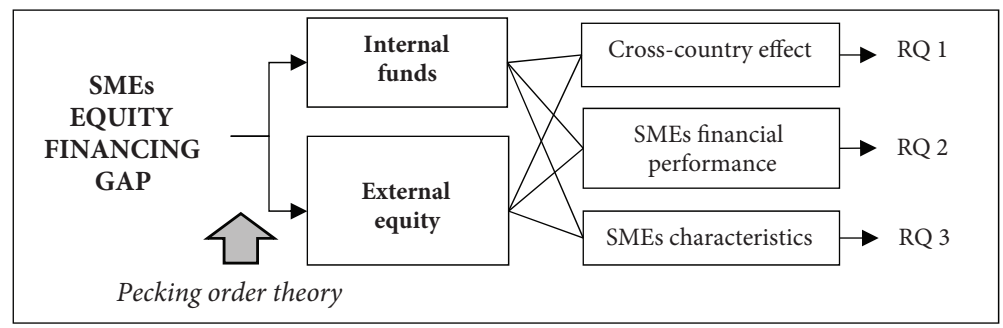

Figure 1. The design of the empirical investigation

confirmed to influence the likelihood of SMEs accessing market-based finance (including issue of new shares) in the recent study by Bongini et al. (2019). However, some studies provided contrary results and suggested that firm-specific factors (such as: age, size, profitability, asset structure, growth rate, ownership structure) are more important (e.g. Psillaki \& Daskalakis, 2009; Arsov \& Naumoski, 2016). Thus, the presented investigations address this issue by examining variables related to SMEs financial performance and SMEs characteristics (see Table 2).

Sample. For the purposes of this study a two-dimensional stratification of the sample (EU countries) was adopted. The first dimension refers to the most common classification of the EU member states into "old" (the 15 countries that formed the EU until May 2004) and "new" (the 13 countries that acceded the EU in May 2004 or later). The demarcation between "old" and "new" member states has some merit, provided that "old" EU countries have a longer history in the performance as a union, whereas new member states have benefited numerous supportive programmes before and shortly after the accession. This stratification is consistent with the study by Kędzior (2012) in which different corporate capital structures in new and old EU member states as well as different capital structure determinants were subject of investigation.

The second dimension of sample stratification refers to the distinction between core and periphery EU countries. There are different concepts on which countries conform the core of the EU (see e.g. Bartlett \& Prica, 2017; Bruha \& Kocenda, 2018). Obviously, the inclusion of a given EU country to the EU core depends on the investigated issue and the related economic variables taken into account. This study, to some extent, follows the distinction provided by Bartlett and Prica (2017, p. 12), who distinguished between "inner core", "outer core", "inner peripheral", "outer peripheral". With reference to this distinction, in this study the cluster of "inner core" countries embraces 6 EU founders and the UK, as one of the biggest net contributors to the EU budget (Kovacevic, 2019). The remainder 8 "old" EU countries are regarded as "outer core". Further, in the group of "new" EU member countries a distinction was made between "inner periphery" that embraces 7 countries in the Eurozone and "outer peripheral" with 6 countries outside Eurozone (see Table 1).

Data. This study relies on the results of the Survey of Access to Finance of Enterprises (SAFE), which is the joint survey of European Commission and European Central Bank. The SAFE survey is published annually (since 2013) and covers all EU member states. The investigation considers the results of five consecutive annual SAFE reports, for 2014-2018 time span (2013 was excluded, as the structure of survey in 2013 was slightly different in comparison to 
Table 1. EU member states stratification - core vs. peripheral countries

\begin{tabular}{|l|l|l|}
\hline \multicolumn{1}{|c|}{ Group } & \multicolumn{1}{c|}{ Countries } & \multicolumn{1}{c|}{ Reasoning } \\
\hline $\begin{array}{l}\text { INNER_C } \\
\text { (inner core) }\end{array}$ & $\begin{array}{l}\text { Germany, France, Belgium, Luxem- } \\
\text { bourg, the Netherlands, Italy, UK }\end{array}$ & $\begin{array}{l}\text { Founders of the EU and UK as the } \\
\text { largest net contributor }\end{array}$ \\
\hline $\begin{array}{l}\text { OUTER_C } \\
\text { (outer core) }\end{array}$ & $\begin{array}{l}\text { Austria, Denmark, Ireland, Finland, } \\
\text { Sweden, Portugal, Greece, Spain }\end{array}$ & $\begin{array}{l}\text { The remainder "old" EU member } \\
\text { states }\end{array}$ \\
\hline $\begin{array}{l}\text { INNER_P } \\
\text { (inner peripheral) }\end{array}$ & $\begin{array}{l}\text { Cyprus, Malta, Estonia, Latvia, } \\
\text { Lithuania, Slovenia, Slovakia }\end{array}$ & $\begin{array}{l}\text { "New" EU member states (since 2004 } \\
\text { or later), in the Eurozone }\end{array}$ \\
\hline $\begin{array}{l}\text { OUTER_P } \\
\text { (outer peripheral) }\end{array}$ & $\begin{array}{l}\text { Czech Republic, Hungary, Croatia, } \\
\text { Bulgaria, Romania, Poland }\end{array}$ & $\begin{array}{l}\text { "New" EU member states (since 2004 } \\
\text { or later), outside the Eurozone }\end{array}$ \\
\hline
\end{tabular}

surveys in 2014 onwards). The SAFE survey sample includes randomly selected firms from different EU countries, different sectors and of different size. In 2018 there were over 17000 survey respondents (SAFE). Previous results of the SAFE survey have been used in several studies so far e.g. Ferrando et al. (2017) or Bongini et al. (2019).

Variables. The SAFE survey is based only on closed questions and the respondents (SMEs' representatives: owners or managers) are asked to choose one of the answers. The survey results are presented in aggregated form, broken by each EU member state. More specifically, for a given closed question, the database provides a percentage structure of answers and it is derived from the answers of respondents (SMEs' representatives) in the given EU country. The methodology of survey data presentation is relevant for the design of the empirical investigation. In the first step, the variables that are related to the purpose of this study (see Table 2) were selected. In this regard, the study is focused on survey questions that asked on the relevance of two sources of funds: (i) internal funds (retained earnings and sale of assets); (ii) external equity. The related survey questions have asked whether the given source of financing was relevant to a firm, that was used in the past or a future use of this source was considered. In the empirical investigation only the fraction (percentage) of answers stating "yes" was included.

Table 2. Variables and their survey-based proxies

\begin{tabular}{|l|l|}
\hline \multicolumn{1}{|c|}{ Variables } & \multicolumn{1}{|c|}{$\begin{array}{c}\text { Proxies based on survey questions and answers - for a given EU country, } \\
\text { as the percentage of SMEs that: }\end{array}$} \\
\hline \multicolumn{1}{|c|}{ SET 1: Variables related to sources of funds } \\
\hline INTERNAL & $\begin{array}{l}\text { Declared relevance of internal funds (retained earnings and sales of assets were } \\
\text { used over the past 6 months or are considered to be used in the future) }\end{array}$ \\
\hline EXTERNAL & $\begin{array}{l}\text { Declared relevance of external equity (external equity was used over the past } 6 \\
\text { months or is considered to be used in the future) }\end{array}$ \\
\hline TURNOVER & \multicolumn{1}{|c|}{ SET 2: Variables related to financial position of SMEs } \\
\hline COST_labour & $\begin{array}{l}\text { Declared no increase of turnover over the past 6 months } \\
\text { months }\end{array}$ \\
\hline COST_other & $\begin{array}{l}\text { Declared increase of other operating costs (materials, energy, others) over the } \\
\text { past 6 months }\end{array}$ \\
\hline
\end{tabular}


End of Table 2

\begin{tabular}{|c|c|}
\hline Variables & $\begin{array}{c}\text { Proxies based on survey questions and answers - for a given EU country, } \\
\text { as the percentage of SMEs that: }\end{array}$ \\
\hline COST_interests & Declared increase of interest expenses paid for debts over the past 6 months \\
\hline PROFIT & Declared no increase of profits (net income after tax) over the past 6 months \\
\hline INVEST_F & $\begin{array}{l}\text { Declared increase of investments in fixed assets (property, plant, machinery or } \\
\text { equipment) over the past } 6 \text { months }\end{array}$ \\
\hline INVEST_C & $\begin{array}{l}\text { Declared increase of investment in current assets (inventory and working } \\
\text { capital) over the past } 6 \text { months }\end{array}$ \\
\hline $\mathrm{D} / \mathrm{A}$ & Declared increase of debt relative to assets over the past 6 months \\
\hline \multicolumn{2}{|r|}{ SET 3. Variables related to SMEs characteristics } \\
\hline SIZE_XS & Employment up to 9 workers (micro) \\
\hline SIZE_S & Employment between 10-49 workers (small) \\
\hline SIZE_M & Employment between 50-249 workers (medium) \\
\hline B_Industry & Declared industry as their main operating activity \\
\hline B_Construction & Declared construction as their main operating activity \\
\hline B_Trade & Declared trade as their main operating activity \\
\hline B_Services & Declared services as their main operating activity \\
\hline O_Family & Represent family businesses, with multiple owners \\
\hline O_Single & Perform as single-owned enterprises \\
\hline O_Other & Perform in other forms than family businesses or single-owned enterprises \\
\hline AGE_XY & Were first registered up to 5 years ago (very young) \\
\hline AGE_Y & Were first registered between 5 and 10 years ago (young) \\
\hline AGE_M & Were first registered more than 10 years ago (mature) \\
\hline
\end{tabular}

The second set of variables refers to the indicators that may potentially signalise the worsening of the SMEs' financial situation and in this context increased SMEs' financing needs. The study considers here the survey questions that have asked respondents on the trend observed in the past 6 months in the following indicators: turnover, labour costs, other operating costs, interest expenses, profit, investments in fixed and current assets and debt to assets ratio. In each case, as a variable only the fraction of SMEs' answers that reflect the downward circumstances (worsening or stagnation) is considered.

The third set of variables is related to the basic characteristics of surveyed SMEs, as regards their size (measured by number of employees), age (duration of performance), ownership structure and the branch of main activity. In each case, the percentage structure of survey respondents in a given country is considered.

Method. The empirical investigation was performed in two steps. First, non-parametric analysis (the Kruskal-Wallis test and the post-hoc tests) was performed to detect whether there are statistically significant differences between the clusters of countries with reference to the first set of variables: the relevance of given source of funds. More specifically, it was tested whether the SMEs declarations on the relevance of a given source of equity financing (internal funds or external equity) were related to the cluster of the EU countries. Driving 
upon these results, further an expanded analysis of the underlying differences in SMEs declarations was performed, based on the analysis of correlations between the variables related to sources of funds and the set of variables related to financial position of SMEs and SMEs characteristics. The obtained correlation ratios were compared between the clusters of countries, according to the significance confirmed previously in non-parametric tests.

\section{Results and discussion}

\subsection{Relevance of equity financing in SMEs - some general considerations}

In this section some overall facts and figures on the relevance of equity financing in surveyed SMEs is presented, in the 2014-2018 time span. In addition, the problem of accessibility of funds is addressed, as ranked among one of the most compelling issues faced currently by the surveyed SMEs. As presented in Figure 2, the percentage of surveyed SMEs that have declared that access to finance remains a core concern in their performance declined in all groups of countries, which suggest the relative decrease of SMEs financing gap. Only in several countries (Greece and Cyprus) c.a. 15\% of surveyed SMEs still perceive access to finance as problematic. However, in these countries we observe also the most significant improvement of the situation.

As this study is primarily concerned with the perceived relevance of equity financing both internal funds and external equity, in Figures 3 and 4 the answers of the surveyed SMEs

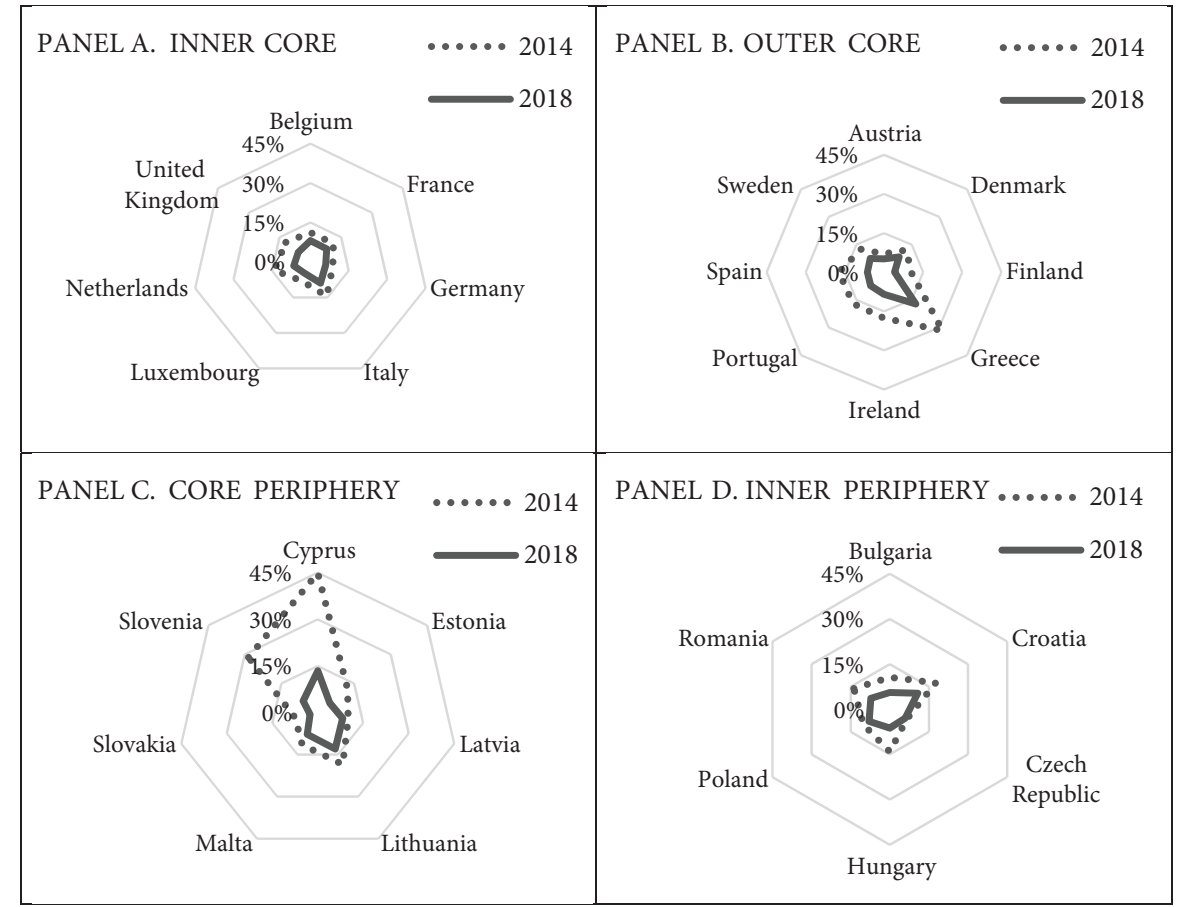

Figure 2. The percentage of surveyed SMEs that pointed on access to finance as one of most important problem currently faced 
in this regard are presented. The graphs reflect the percentage of SMEs that have answered "yes" to the question on the relevance of a given source of financing (consistently with survey methodology, as outlined in Table 2).

Data presented in Figure 3 indicate that there are several countries where internal funds is very relevant for SMEs (e.g. Sweden). The internal funds are visibly more relevant for SMEs performing in inner periphery and outer periphery countries (above 25\% in most of the cases), and Croatia and Malta distinguish with the highest relevance in their country clusters. In general, if we compare the SMEs declarations in dynamic context (changes in the time span 2014-2018), in most of the countries the SMEs declarations on the relevance of internal funds remain comparable. However, there are some exceptions: Denmark, Portugal and Spain, with a sharp decline.

Data presented in Figure 4 show that the external equity seems to be less important for inner core countries, in comparison to outer core countries (as in the majority of countries

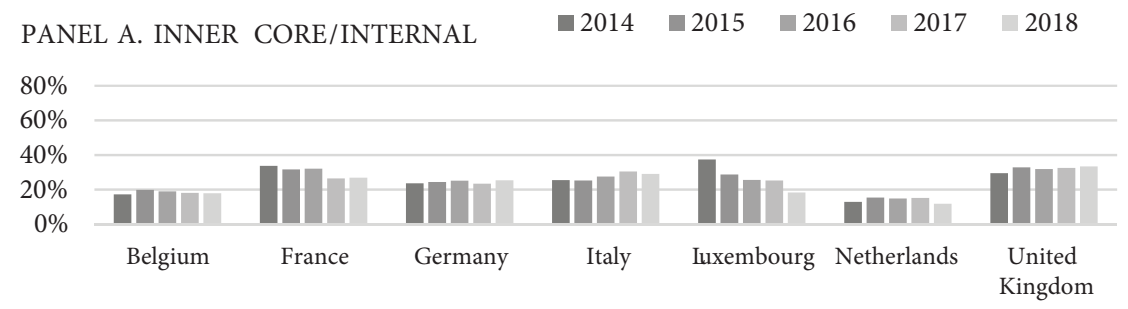

PANEL B. OUTER CORE/INTERNAL $\square 2014 \square 2015 \quad \square 2016 \quad \square 2017 \square 2018$

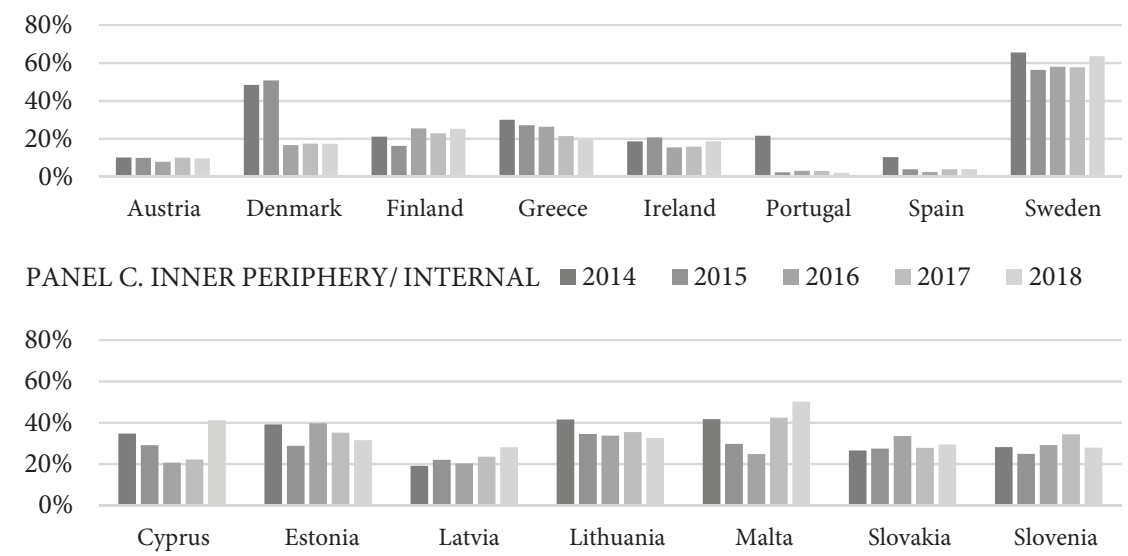

PANEL D. OUTER PERIPHERY/INTERNAL $\square 2014 \quad \square 2015 \square 2016 \square 2017 \square 2018$

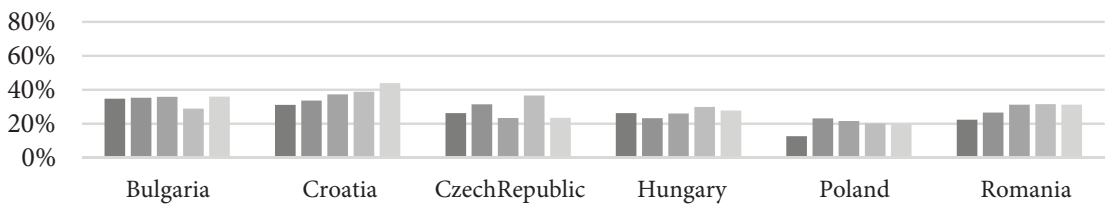

Figure 3. The percentage of surveyed SMEs that declared relevance of internal funds 
1552 M. Wieczorek-Kosmala et al. Comparative study of the relevance of equity financing in European SMEs

PANEL A. INNER CORE / EXTERNAL $\quad 2014 \quad \square 2015 \quad \square 2016 \quad \square 2017 \quad \square 2018$

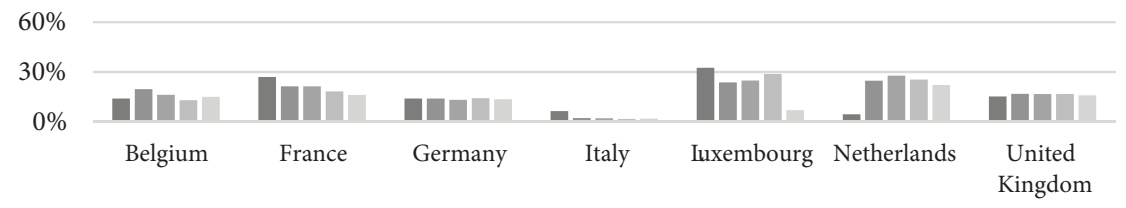

PANEL B. OUTER CORE/EXTERNAL $\quad 2014 \quad \square 2015 \quad \square 2016 \quad \square 2017 \quad \square 2018$

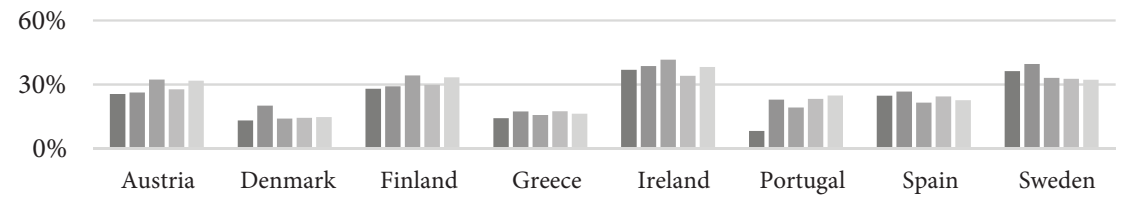

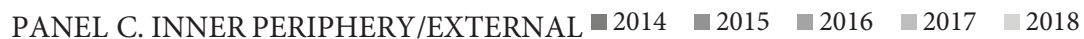

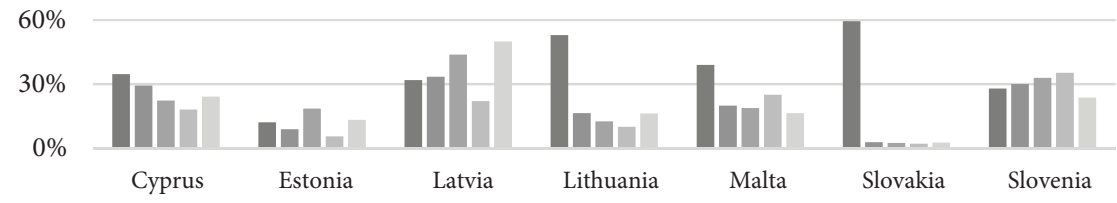

PANEL D. OUTER PERIPHERY/EXTERNAL $2014 \backsim 2015 \square 2016 \square 2017 \square 2018$

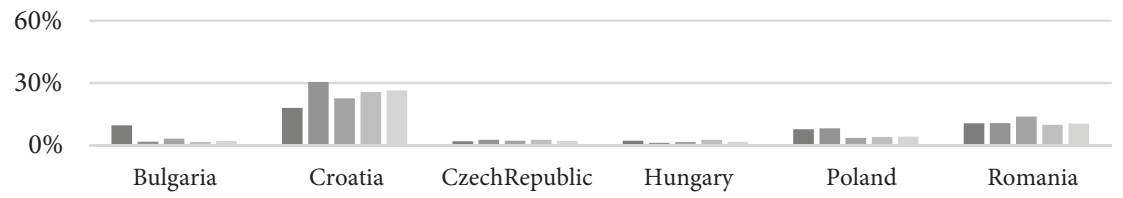

Figure 4 . The percentage of surveyed SMEs that declared relevance of external equity

in this cluster - except from Denmark and Greece, more than 25\% of the surveyed SMEs declared the relevance of external equity). In dynamic context, the least stable situation over the analysed period was observed in the case of the cluster of inner periphery countries. In some countries, in 2014 the SMEs declared external equity to be very relevant, which was followed by a significant decline in further years (Malta, Lithuania and Slovakia). The cluster of outer peripheral countries (except Croatia) demonstrates very low rates in comparison to other clusters.

\subsection{Relevance of equity financing in SMEs in country-specific context}

In order to investigate the possible importance of the country specifics on the declared relevance of equity financing in SMEs, non-parametric tests were performed to compare the groups of countries in this regard. The results of Kruskal-Wallis test presented in Table 3 clearly indicate that there is a statistically significant difference between the declared relevance of internal funds or external equity in SMEs, if we consider the group of countries 
in which these SMEs are domiciled. In terms of the demarcation between old and new EU member states, the results are significant for internal funds only.

Table 3. The results of Kruskal-Wallis test for the relevance of sources of equity financing and the dimension of countries stratification

\begin{tabular}{|l|c|c|}
\hline \multicolumn{1}{|c|}{ Country stratification } & Internal funds & External equity \\
\hline 1: Old vs. new EU member states & $10.799^{* * *}$ & 1.861 \\
\hline 2: Core and peripheral EU member states & $12.411^{* * *}$ & $26.376^{\star * *}$ \\
\hline
\end{tabular}

Note: Statistical significance at: ${ }^{\star * \star} \alpha=0.001$.

Further, the post-hoc tests (comparisons between two group of countries) results were analysed to detect for which groups of countries the differences are most significant. The results are presented in graphical form (the boxplots) in Figure 5.

On average, the percentage of SMEs that declared the relevance of internal funds was higher in the cluster of new EU, as compared to the cluster of the old EU (Figure 5, panel A). Further, on average, the percentage of SMEs that declared the relevance of internal funds

PANEL A. Internal funds and clusters of EU countries in first stratification

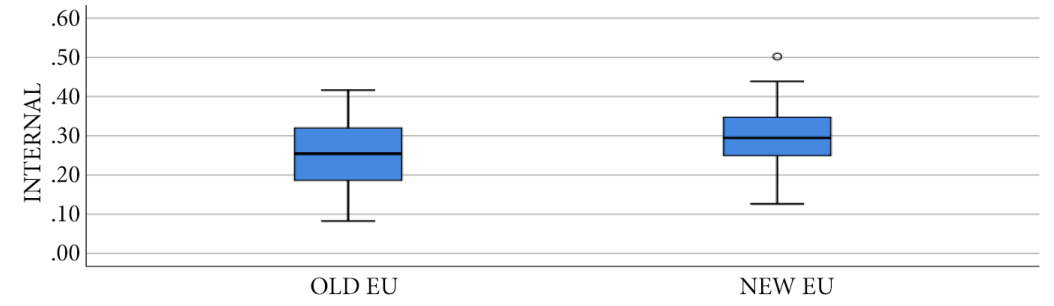

PANEL B. Internal funds and the clusters of EU countries in second stratification

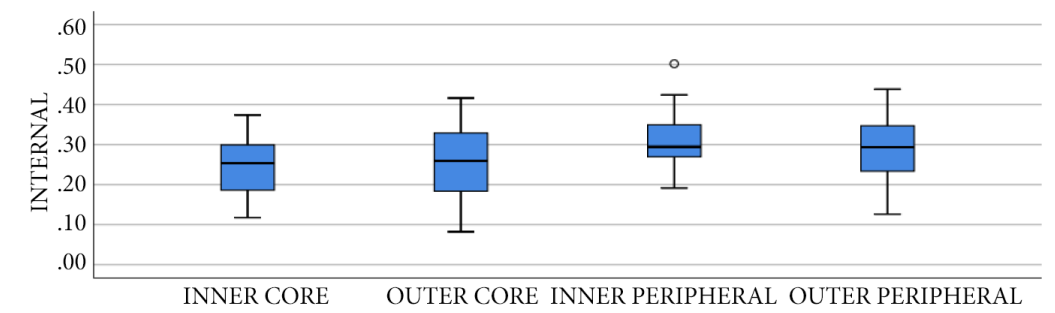

PANEL C.External equity and the clusters of EUcountries in second stratification

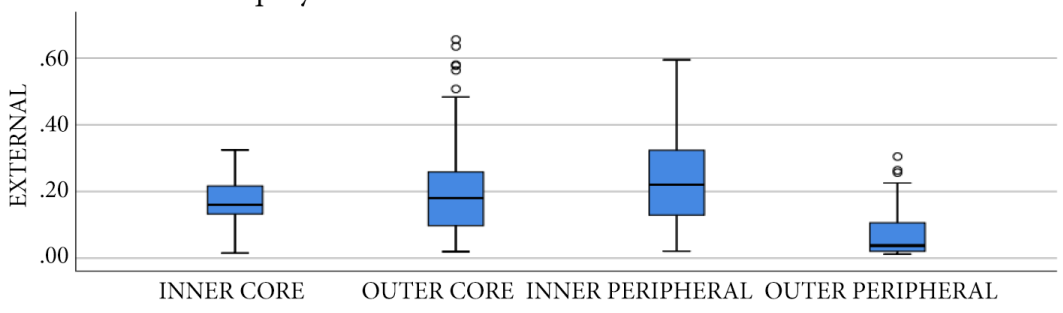

Figure 5. The boxplots for significant differences between the clusters of EU countries in terms of equity financing (extension of Kruskal-Wallis test) 
was higher in the cluster of inner peripheral countries in comparison to the cluster of inner core (panel B). Finally, with respect to external equity, there were statistically significant differences between the cluster of outer peripheral countries and all other clusters. More specifically, the boxplot indicates that on average, the percentage of SMEs that declared the relevance of external equity in the cluster of outer peripheral countries was significantly lower in comparison to all other clusters (panel C). It suggests that the declared relevance of external equity for SMEs domiciled in new EU member states that remain outside the Eurozone was significantly different. In this regard, the answer for the first of research questions placed (RQ1) is positive, as we obviously observe a statistically significant differences in the relevance of equity financing in cross-country dimension. These differences could be driven by the unique business environment in each country, as well as by the firm-specific factors. Thus, there is a rationale behind further inquiries that allow to detect the factors that may potentially shed some light on these differences. In this context, we refer in further sections to variables of SMEs performance and SMEs characteristics with a focus on second dimension of countries stratification (as in this aspect the cross-country differences were found statistically significant for both internal funds and external equity).

\subsection{Relevance of equity financing in SMEs and SMEs performance}

In Table 4 the Pearson correlation coefficients for a type of equity financing (internal funds or external equity) and the variables that indicate SMEs performance are presented. The correlation coefficients were computed for all time-country observations, broken by the stratification dimension of core vs. peripheral countries. This analysis was designed not only to detect whether there were any statistically significant correlations, but also to compare the significance of these correlations between the groups (clusters) of countries. The variables that illustrate SMEs performance reflect the surveyed SMEs declarations on the change of a given variable that corresponds to downward circumstances and the related possibility of the worsening of financial performance in this regard (e.g. increase of costs or no improvement of turnover or profit). By intuition, it is assumed that the worsening of financial situation increases the capital needs. However, one should remember that in this survey SMEs were asked about the real use of internal funds or external equity. In this respect, the availability of internal funds and external equity is limited, if the performance worsens. This reasoning is highlighted here, as it should be taken into account in terms of the interpretation of the signs of correlation coefficients.

Nevertheless, the data presented in Table 4 indicate that there is no unified pattern of correlations and thus it is difficult to indicate the list of variables that emerged as relevant in all cases (and in each cluster of countries). However, in the cluster of outer core countries, the declared relevance of internal funds was related to worsening of turnover and profit, increased costs of labour and investments in fixed and current assets, and increased leverage. Relatively similar pattern of significant correlations is observed in the case of inner periphery countries. There are visibly less significant correlations observed in the case of the declared relevance of external equity financing and indicators of SMEs performance. Moreover, in the case of outer periphery countries there are no statistically relevant correlations. 
The data allow to answer positively on the second research question (RQ2) only partially, as there are clusters of countries for which no significant correlations were found (outer periphery). In this regard, the obtained results support also the previous conclusion on the existence of cross-countries differences, as there is no obvious pattern of correlations that emerges from our analysis.

Table 4. The Pearson correlation coefficients for the relevance of equity financing and the proxies of SMEs financial performance

\begin{tabular}{|c|c|c|c|c|c|c|c|c|}
\hline \multirow[b]{2}{*}{ Specification } & \multicolumn{4}{|c|}{ Internal funds } & \multicolumn{4}{|c|}{ External equity } \\
\hline & $\begin{array}{l}U_{1} \\
\text { 壵 } \\
\text { 贡 }\end{array}$ & 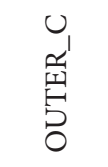 & 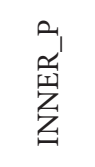 & 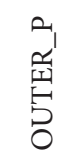 & $\begin{array}{l}U_{1} \\
\text { 荘 } \\
\text { 艺 }\end{array}$ & 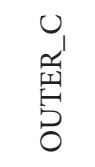 & $\begin{array}{l}\text { 岁 } \\
\text { 岁 } \\
\text { 号 }\end{array}$ & 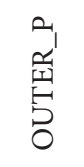 \\
\hline TURNOVER & .329 & $-.496^{* *}$ & -.280 & .042 & $-.395^{\star}$ & -.293 & .116 & -.087 \\
\hline COST_labour & .065 & $.514^{\star *}$ & $.401^{\star}$ & -.029 & .168 & .111 & $-.336^{*}$ & -.346 \\
\hline COST_other & $.379^{*}$ & .109 & .322 & -.005 & -.267 & $-.332^{\star}$ & .039 & -.009 \\
\hline COST_interests & .254 & -.253 & $.411^{*}$ & .034 & $-.464^{\star \star}$ & -.270 & .286 & .107 \\
\hline PROFIT & $.502^{\star \star}$ & $-.482^{* *}$ & $-.339^{*}$ & .193 & -.280 & -.278 & .171 & -.052 \\
\hline INVEST_F & .241 & $.322^{\star}$ & .165 & .048 & -.046 & -.020 & .045 & .071 \\
\hline INVEST_C & $-.340^{\star}$ & $.519^{* *}$ & $.379^{*}$ & .098 & .213 & .077 & -.052 & .294 \\
\hline $\mathrm{D} / \mathrm{A}$ & .204 & $-.353^{*}$ & $.344^{*}$ & -.193 & $-.476^{\star \star}$ & -.147 & .208 & -.059 \\
\hline
\end{tabular}

Note: Statistical significance at: ${ }^{\star *} \alpha=0.01 ;{ }^{*} \alpha=0.05$.

\subsection{Relevance of equity financing in SMEs and SMEs characteristics}

Table 5 presents the Pearson correlation coefficients for a type of equity financing (internal funds or external equity) and the variables that reflect the common characteristics of SMEs. The correlation coefficients were computed for all time-country observations, broken by the stratification dimension of core vs. peripheral countries. The purpose of this analysis is similar as in the case of SMEs performance and was designed to compare the significance of correlations between the groups (clusters) of countries.

The variables that reflect SMEs characteristics indicate the percentage of SMEs that declared their belonging to a given type of SMEs (concerning age, branch, ownership or size). Thus, the signs of correlations coefficients reflect the course of the changes of a percentage of SMEs that found a given type of financing relevant and the changes in the percentage of SMEs that declared to fit a given group of SMEs, by its characteristics.

The correlations presented in Table 5 allow to capture some significant relationships between the relevance of internal funds or external equity and SMEs characteristics, as for particular clusters of the EU countries. Only in the case of internal funds and inner core countries no statistically significant correlations were found. In this respect, a positive answer for the third research question asked in this study (RQ 3) found partial support. However, as it was in the case of SMEs performance, there is no obvious unified pattern of correlations 
Table 5. The Pearson correlation coefficients for the relevance of equity financing and the proxies of SMEs characteristics

\begin{tabular}{|c|c|c|c|c|c|c|c|c|}
\hline \multirow[b]{2}{*}{ Specification } & \multicolumn{4}{|c|}{ Internal funds } & \multicolumn{4}{|c|}{ External equity } \\
\hline & 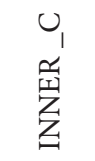 & 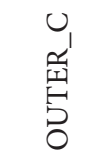 & 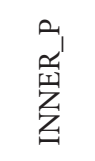 & 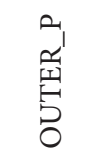 & 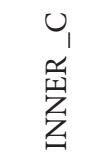 & 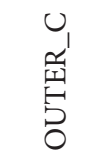 & 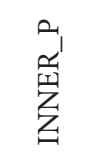 & 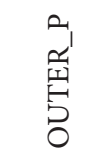 \\
\hline SIZE_XS & -.137 & $-.451^{* *}$ & -.199 & $-.462^{\star}$ & $-.451^{* *}$ & -.263 & -.079 & -.206 \\
\hline SIZE_S & .322 & $.458^{\star *}$ & .135 & $.583^{\star *}$ & $.355^{\star}$ & .203 & .156 & 200 \\
\hline SIZE_M & .011 & $.438^{\star *}$ & .235 & .193 & $.492^{\star *}$ & .305 & .001 & .159 \\
\hline B_INDUSTRY & -.002 & .302 & .124 & .129 & $-.654^{* *}$ & .210 & .148 & .028 \\
\hline B_Construction & -.084 & .004 & .234 & .048 & -.133 & -.093 & -.018 & .018 \\
\hline B_Trade & -.032 & -.289 & -.035 & -.198 & .219 & -.045 & .024 & -.108 \\
\hline B_Services & .135 & .168 & $-.397^{\star}$ & .147 & .307 & .116 & -.071 & .142 \\
\hline O_Fam & .164 & -.194 & .248 & -.338 & $-.555^{\star *}$ & $-.440^{* *}$ & -.007 & $-.672^{\star *}$ \\
\hline O_Singl & -.291 & .209 & $-.366^{\star}$ & $.655^{\star *}$ & .176 & .125 & -.015 & $.653^{\star *}$ \\
\hline O_Other & .080 & .106 & .093 & $-.447^{\star}$ & $.498^{\star *}$ & $.649^{\star *}$ & .037 & .025 \\
\hline AGE_XY & .009 & .206 & -.110 & .064 & .116 & .194 & $-.389^{\star}$ & .224 \\
\hline AGE_Y & .168 & -.024 & -.015 & .193 & .079 & $.447^{\star *}$ & -.031 & -.266 \\
\hline AGE_M & -.117 & -.092 & .063 & -.158 & -.105 & $-.383^{\star}$ & .205 & .075 \\
\hline
\end{tabular}

Note: Statistical significance at: ${ }^{*} \alpha=0.01 ;^{\star} \alpha=0.05$.

that is repeated across the countries. In other words, on the level of countries stratification adopted in this study (and the related clusters), the cross-country differences are clearly visible.

\section{Conclusions}

With reference to the relevance of the problem of SMEs financing, this study aimed at shedding some light on the equity financing gap in SMEs. In particular, consistently with the assumptions of bridged pecking order theory, it was focused on the relevance of internal funds (retained earnings or sales of assets) and external equity.

In the design of empirical investigation the study addressed country specifics, which was reflected by the two-dimensional stratification of the EU member states and the analysis of the obtainable survey data on SMEs financing for several clusters of the EU countries. In this regard, it was found that there are statistically significant differences on the relevance of internal funds and external equity in SMEs between the compared clusters of countries. The most interesting differences are observed between the "outer peripheral" countries and the countries in clusters "inner peripheral", "outer core" and "inner core". This simply indicates that the declared relevance of external equity for SMEs domiciled in new EU member states that remain outside the Eurozone was significantly different from the declared relevance of 
external equity in the remainder group of countries. The observed differences could be driven by a variety of factors, such as economic recovery after the global financial crisis, development of the traditional capital markets as well as the alternative finance solutions, easing monetary policy or EU or state aid programmes for SMEs.

In the expanded analysis, the study aimed at detecting whether there are any SMEs performance-related or SMEs characteristics-related factors that may potentially explain the relevance of internal funds and external equity in SMEs, within the clusters of EU countries of interest. However, the investigation clearly leads to the conclusion that there is no unified pattern of associations for all analysed clusters of countries, and thus the conclusion is that the relevance of internal funds or external equity remains highly country-specific issue. To some extent, these findings correspond with the introductory comparison of the surveyed SMEs declarations on the relevance of equity financing we performed. In some countries the relevance of equity financing was at very low level (e.g. external equity in Italy or in outer peripheral countries) and in some countries it has dropped significantly over the analysed period of time. In this context, this study helped to highlight the need for future and more detailed research endeavours that could shed some light on the observed differences. In particular, further inquiries shall be placed on whether the low relevance of external equity is related to the accessibility of other financing (e.g. dedicated state or EU programs that enhance SMEs support or the development of crowdfunding platforms reducing the capital gap, especially in the early stages of life cycle), or - on the contrary - lack of such mechanisms which leads to some difficulties in obtaining equity financing by SMEs (e.g. venture capital or business angels related programmes). In this context, this study contributes to discussion over the existence of bridged pecking order theory in SMEs.

This study faces some limitations resulting from the nature of the survey data available from SAFE. More specifically, the main limitations come from the analysis of declarations of SMEs and the fact that these declarations are presented as a fraction (percentage) of SMEs answers to a given question. However, an attention was paid to the application of adequate statistical methods that allowed to draw unbiased conclusions on the country specifics and relevance of internal funds and external equity in SMEs.

\section{Author contributions}

MWK and JB conceived this study and were responsible for its conceptual design. JB wrote the literature review. MWK was responsible for research design and method. JB collected the data and JT was responsible for data processing and statistical analysis. MWK and JT jointly interpreted the data. MWK wrote sections 2 and 3, the introduction and conclusions.

\section{Disclosure statement}

Authors declare that they do not have any competing financial, professional, or personal interests from other parties. 


\section{References}

Adair, P., \& Adaskou, M. (2015). Trade-off-theory vs. pecking order theory and the determinants of corporate leverage: Evidence from a panel data analysis upon French SMEs (2002-2010). Cogent Economics \& Finance, 3(1), 1-12. https://doi.org/10.1080/23322039.2015.1006477

Andrieu, G., Staglianò, R., \& Van Der Zwan, P. (2018). Bank debt and trade credit for SMEs in Europe: firm-, industry-, and country-level determinants. Small Business Economics, 51(1), 245-264. https://doi.org/10.1007/s11187-017-9926-y

Allen, D. E. (1993). The pecking order hypothesis: Australian evidence. Applied Financial Economics, 3(2), 101-112. https://doi.org/10.1080/758532828

Arsov, S., \& Naumoski, A. (2016). Determinants of capital structure: An empirical study of companies from selected post-transition economies. Zbornik radova Ekonomskog fakulteta u Rijeci: časopis $z a$ Ekonomsku Teoriju i Praksu, 34(1), 119-146. https://doi.org/10.18045/zbefri.2016.1.119

Baker, M., \& Wurgler, J. (2002). Market timing and capital structure. Journal of Finance, 57(1), 1-32. https://doi.org/10.1111/1540-6261.00414

Bartlett, W., \& Prica, I. (2017). Interdependence between core and peripheries of the European economy: secular stagnation and growth in the Western Balkans. European Journal of Comparative Economics, 14(1), 123-139. https://doi.org/10.2139/ssrn.2729882

Baskin, J. (1989). An empirical investigation of the pecking order hypothesis. Financial Management, 18(1), 26-35. https://doi.org/10.2307/3665695

Bistrova J., Lace, N., \& Peleckiene, V. (2011). The influence of capital structure on Baltic corporate performance. Journal of Business Economics and Management, 12(4), 655-669. https://doi.org/10.3846/16111699.2011.599414

Bongini, P., Ferrando, A., Rossi, E., \& Rossolini, M. (2019). SME access to market-based finance across Eurozone countries. Small Business Economics, 1-31. https://doi.org/10.1007/s11187-019-00285-z

Bruha, J., \& Kocenda, E. (2018). Financial stability in Europe. Banking and sovereign risk. Journal of Financial Stability, 36, 305-321. https://doi.org/10.1016/j.jfs.2018.03.001

Bulan, L. T., \& Zhipeng, Y. (2010, August 12). Firm maturity and the pecking order theory. SSRN. https://doi.org/10.2139/ssrn.1760505

Carpenter, R. E., \& Petersen, B. C. (2002). Capital market imperfections, high-tech investment, and new equity financing. The Economic Journal, 112(477), F54-F72. https://doi.org/10.1111/1468-0297.00683

Colombo, M. G., \& Grilli, L. (2007). Funding gaps? Access to bank loans by high-tech start-ups. Small Business Economics, 29(1-2), 25-46. https://doi.org/10.1007/s11187-005-4067-0

Cowling, M., Liu, W., \& Ledger, A. (2012). Small business financing in the UK before and during the current financial crisis. International Small Business Journal, 30(7), 778-800. https://doi.org/10.1177/0266242611435516

Daskalakis, N., Jarvis, R., \& Schizas, E. (2013). Financing practices and preferences for micro and small firms. Journal of Small Business and Enterprise Development, 20(1), 80-101. https://doi.org/10.1108/14626001311298420

Deffains-Crapsky, C., \& Sudolska, A. (2014). Radical innovation and early stage financing gaps: equitybased crowdfunding challenges. Journal of Positive Management, 5(2), 3-19. https://doi.org/10.12775/JPM.2014.009

Delcoure, N. (2007). The determinants of capital structure in transitional economies. International Review of Economics \& Finance, 16(3), 400-415. https://doi.org/10.1016/j.iref.2005.03.005

Donaldson, G. (2000). Corporate debt capacity: A study of corporate debt policy and the determination of corporate debt capacity. Beard Books (Original work published 1961). 
Dong, M., Loncarski, I., Horst, J. T., \& Veld, C. (2012). What drives security issuance decisions: Market timing, pecking order, or both? Financial Management, 41(3), 637-663. https://doi.org/10.1111/j.1755-053X.2012.01213.x

Dowling, M., O’gorman, C., Puncheva, P., \& Vanwalleghem, D. (2019). Trust and SME attitudes towards equity financing across Europe. Journal of World Business, 54(6). https://doi.org/10.1016/j.jwb.2019.101003

Durvy, M. J. N. (2007). Equity Financing for SMEs: "The nature of the market failure". In The SME Financing Gap (Vol. II): Proceedings of the Brasilia Conference, 27-30 March 2006 (Vol. 2, p. 126). OECD Publishing.

Ferrando, A., Popov, A., \& Udell, G. F. (2017). Sovereign stress and SMEs' access to finance: Evidence from the ECB's SAFE survey. Journal of Banking \& Finance, 81, 65-80. https://doi.org/10.1016/j.jbankfin.2017.04.012

Frank, M. Z., \& Goyal, V. K. (2003). Testing the pecking order theory of capital structure. Journal of Financial Economics, 67(2), 217-248. https://doi.org/10.1016/S0304-405X(02)00252-0

Haas, R., \& Peeters, M. (2006). The dynamic adjustment towards target capital structure of firms in transition economies. Economics of Transition, 14, 133-169. https://doi.org/10.1111/j.1468-0351.2006.00237.x

Jong, A., Verbeek, M., \& Verwijmeren, P. (2011). Firms' debt-equity decisions when the static tradeoff theory and the pecking order theory disagree. Journal of Banking \& Finance, 35(5), 1303-1314. https://doi.org/10.1016/j.jbankfin.2010.10.006

Kersten, R., Harms, J., Liket, K., \& Maas, K. (2017). Small Firms, large Impact? A systematic review of the SME Finance Literature. World Development, 97, 330-348. https://doi.org/10.1016/j.worlddev.2017.04.012

Kędzior, M. (2012). Capital structure in EU selected countries - micro and macro determinants. Argumenta Oeconomica, 28, 69-117. http://yadda.icm.edu.pl/yadda/element/bwmeta1.element.ekonelement-000171349731

Koralun-Bereźnicka, J. (2013). How does asset structure correlate with capital structure? - cross-industry and cross-size analysis of the EU countries. Universal Journal of Accounting and Finance, $1(1), 19-28$.

Kovacevic, T. (2019, May 28). EU budget: Who pays most in and who gets most back? BBC News. Retrieved November 11, 2019, from https://www.bbc.com/news/uk-politics-48256318

Kraus, A., \& Litzenberger, R. H. (1973). A state-preference model of optimal financial leverage. Journal of Finance, 33, 911-922. https://doi.org/10.1111/j.1540-6261.1973.tb01415.x

Kumar, S., \& Rao, P. (2015). A conceptual framework for identifying financing preferences of SMEs. Small Enterprise Research, 22(1), 99-112. https://doi.org/10.1080/13215906.2015.1036504

Leland, H. E., \& Pyle, D. H. (1977). Information asymmetries, financial structure, and financial intermediation. Journal of Finance, 32(2), 371-378. https://doi.org/10.2307/2326770

Masiak, C., Moritz, A., \& Lang, F. (2020). European SME financing: An empirical taxonomy. In Contemporary Developments in Entrepreneurial Finance (pp. 3-30). Springer, Cham. https://doi.org/10.1007/978-3-030-17612-9_1

Mason, C. M., \& Harrison, R. T. (1995). Closing the regional equity capital gap: The role of informal venture capital. Small Business Economics, 7(2), 153-172. https://doi.org/10.1007/BF01108688

McNally, K. (1997). Corporate venture capital: Bridging the equity gap in the small business sector. Routledge. https://doi.org/10.4324/9780203443392

Moritz, A., Block, J. H., \& Heinz, A. (2016). Financing patterns of European SMEs - an empirical taxonomy. An International Journal of Entrepreneurial Finance, 16(2), 115-148.

https://doi.org/10.1080/13691066.2016.1145900 
Myers, S. C., \& Majluf, N. S. (1984). Corporate financing and investment decisions when firms have information that investors do not have. Journal of Financial Economics, 13(2), 187-221. https://doi.org/10.1016/0304-405X(84)90023-0

Neely, L., \& Van Auken, H. (2012). An examination of small firm bootstrap financing and use of debt. Journal of Developmental Entrepreneurship, 17(01). https://doi.org/10.1142/S1084946712500021

Nivorozhkin, E. (2004). The dynamics of capital structure in transition economies. Economics of Planning, 37(1), 25-45. https://doi.org/10.1007/s10644-004-1056-2

Ou, C. \& Haynes, G. W. (2006). Acquisition of additional equity capital by small firms - findings from the national survey of small business finances. Small Business Economics, 27(2-3), 157-168. https://doi.org/10.1007/s11187-006-0009-8

Psillaki, M., \& Daskalakis, N. (2009). Are the determinants of capital structure country or firm specific? Small Business Economics, 33(3), 319-333. https://doi.org/10.1007/s11187-008-9103-4

Ross, S. A. (1977). The determination of financial structure: The incentive signalling approach. Bell Journal of Economics, 8, 23-40. https://doi.org/10.2307/3003485

European Commission. (2018). SAFE. https://ec.europa.eu/growth/access-to-finance/data-surveys

Shyam-Sunder, L., \& Myers, S. C. (1999). Testing static tradeoff against pecking order models of capital structure. Journal of Financial Economics, 51(2), 219-244. https://doi.org/10.1016/S0304-405X(98)00051-8

Whittam, G. P. S., \& Wyper, J. (2007). The pecking order hypothesis: does it apply to start-up firms? Journal of Small Business and Enterprise Development, 14(1), 8-21. https://doi.org/10.1108/14626000710727854

Wu, J., Song, J., \& Zeng, C. (2008). An empirical evidence of small business financing in China. Management Research News, 31(12), 959-975. https://doi.org/10.1108/01409170810920666

Zoppa, A., \& McMahon, R. G. P. (2002). Pecking order theory and the financial structure of manufacturing SMEs from Australia's business longitudinal survey. Small Enterprise Research, 10(2), 23-41. https://doi.org/10.5172/ser.10.2.23 